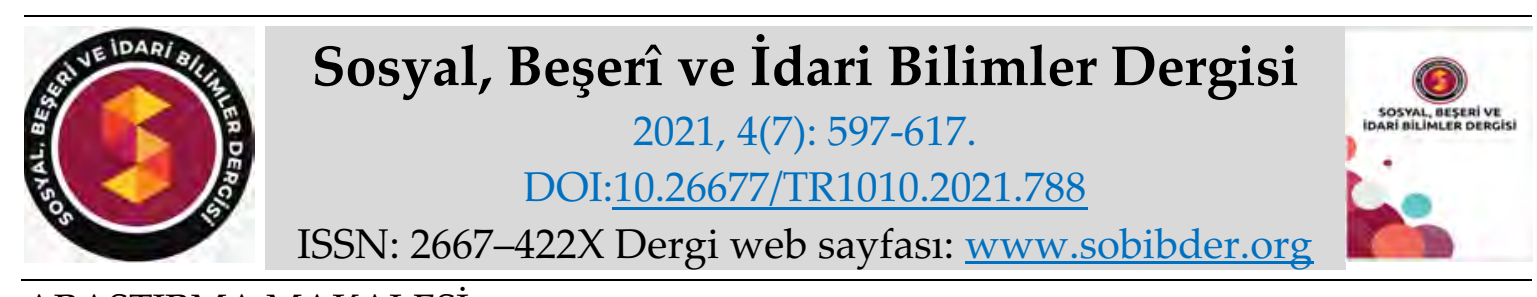

ARASTIRMA MAKALESI

\title{
B1 Düzeyindeki Öğrencilerin Yazılı Anlatımlarındaki Kelime Sıklığı Üzerine Bir Araştırma
}

Prof. Dr. Zekerya BATUR, Uşak Üniversitesi, Eğitim Fakültesi, Uşak, e-posta: zekerya.batur@usak.edu.tr

ORCID: https://orcid.org/0000-0002-7918-5305

Mine ÖZÇELIK, Doktora Öğrencisi, Uşak Üniversitesi, Lisansüstü Enstitüsü, Uşak, e-posta: ozcelik1981@gmail.com

ORCID: https://orcid.org/0000-0002-9941-5577

Arş. Gör. Dr. Ufuk ULUÇINAR, Uşak Üniversitesi, Eğitim Fakültesi, Uşak, e-posta: ufuk.ulucinar@usak.edu.tr

ORCID: https://orcid.org/0000-0001-9167-5457

Öz

Bu çalışmanın amacı, Türkçeyi yabancı dil olarak öğrenen öğrencilerin yazma dersindeki çalışmalarında kullandıkları kelime sayısını, kelime türlerini ve kelime çeşitliliğini incelemektir. Çalışmada, nicel araştırma desenlerinden betimsel tarama modeli kullanılmıştır. Çalışmanın araştırma grubunu Pamukkale Üniversitesi Dil Öğretimi Uygulama ve Araştırma Merkezi'nde B1 düzeyinde Türkçe öğrenen yabancı uyruklu öğrenciler oluşturmaktadır. Çalışma grubunda 10 erkek ve 5 kadın olmak üzere toplam 15 öğrenci yer almaktadır. Araştırmada, çalışma öncesinde yüz yüze öğrenci görüşmeleriyle ve uzman görüşleri alınarak temalar belirlenmiş ve bu kapsamda öğrencilere 6 hafta süre içinde 6 adet kompozisyon yazdırılmıştır. Çalışmada 46 adet -öğrenciler hakkında bilgi edinmek için- kişisel bilgi formu ve 90 adet çalışma kâğıdı taranmıştır. Bu tarama ile öğrencilere yazdırılan yazılarda yer alan kelime sayısı ve kelime türlerinin tespit edilmesi amaçlanmıştır. Öğrencilerin yazma çalışmalarının -üç ayrı temada da ortak olarak- SPSS 25.0 paket programı ile analiz edilmesiyle öğrencilerin en fazla "ve", "sonra", "git-" ve "al-" kelimelerini kullandıkları tespit edilmiştir.

Anahtar Kelimeler: Yazma Becerisi, Kelime, Kelime Sıklığı, B1 Düzeyi.

Makale Gönderme Tarihi: 17.03.2021

Makale Kabul Tarihi: 04.07.2021

Önerilen Atıf:

Batur, Z., Özçelik, M. ve Uluçınar, U. (2021). B1 Düzeyindeki Öğrencilerin Yazılı Anlatımlarındaki Kelime Sıklığı Üzerine Bir Araştırma, Sosyal, Beşeri ve İdari Bilimler Dergisi, 4(7): 597-617.

(c) 2021 Sosyal, Beşerî ve İdari Bilimler Dergisi. 


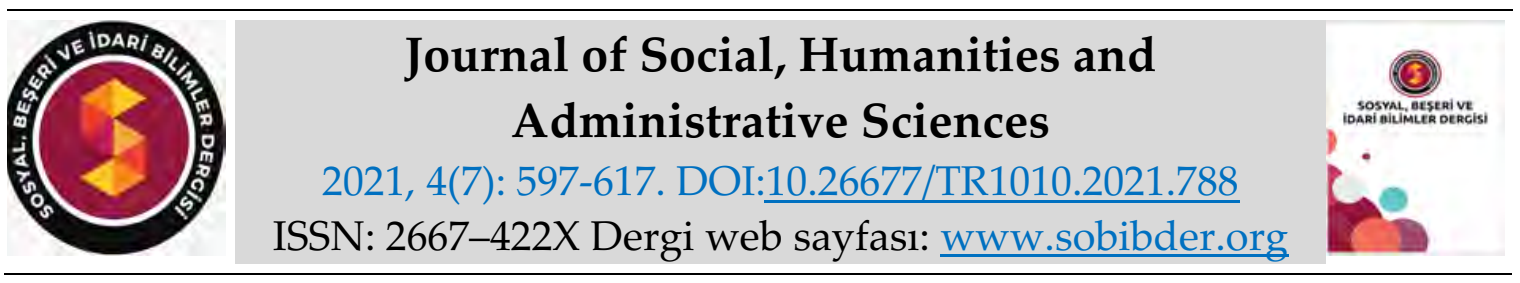

RESEARCH PAPER

\title{
A Research on The Frequency of Words in Written Expressions of B1 Level Students
}

Prof. Dr. Zekerya BATUR, Uşak University, Faculty of Education, Uşak, e-mail: zekerya.batur@usak.edu.tr ORCID: https://orcid.org/0000-0002-7918-5305

Mine ÖZÇELIK, Ph.D. Student, Uşak University, Graduate Institute, Uşak, e-mail: ozcelik1981@gmail.com

ORCID: https://orcid.org/0000-0002-9941-5577

Dr. Ufuk ULUÇINAR, Uşak University, Faculty of Education, Uşak, e-mail: ufuk.ulucinar@usak.edu.tr

ORCID: https://orcid.org/0000-0001-9167-5457

\begin{abstract}
The aim of this study is to examine the number of words, word types and word diversity used by students who learn Turkish as a foreign language in their writing course. The descriptive survey model, one of the quantitative research designs, was used in the study. The research group of the study consists of foreign students who learn Turkish at B1 level in Pamukkale University Language Teaching Application and Research Center. There are 15 students, 10 males and 5 females, in the study group. In the research, before the study, the themes were determined by face-to-face student interviews and expert opinions, and in this context, 6 compositions were written to the students within a period of 6 weeks. In the study, 46 personal information forms and 90 worksheets were scanned to obtain information about students. With this screening, it is aimed to determine the number of words and word types in the articles written to students. By analyzing the writing activities of the students with the SPSS 25.0 package program - with three different themes, it was determined that the students mostly used words "and", "after", "go" and "get".
\end{abstract}

Keywords: Writing Skill, Word, Word Frequency, B1 Level.

Received: 17.03 .2021

Accepted: 04.07.2021

Suggested Citation:

Batur, Z., Özçelik, M. and Uluçınar, U. (2021). A Research on The Frequency of Words in Written Expressions of B1 Level Students, Journal of Social, Humanities and Administrative Sciences, 4(7): 597-617.

(c) 2021 Sosyal, Beşerî ve İdari Bilimler Dergisi. 


\section{GİRIŞ}

Yazma, işittiklerimizi, düşündüklerimizi, tasarladıklarımızı, görüp yaşadıklarımızı, duygularımızı, isteklerimizi yazı aracılığı ile anlatma; zihinde yapılandırılmış bilgilerin yazıya aktarılması, diğer insanlar ile iletişim kurup kendimizi anlatmanın bir yöntemi ve üst düzeyde düşünme aracl, düşünme üzerinde düşünmedir (Güneş, 2007; Öz, 2006; Demirel, 2004; Sever, 2004). Warker (vd., 2005) ise yazmayı bireyin sahip olduğu temel becerileri ve bilgiyi düzenleme yeteneğini içeren karmaşık bir faaliyet olarak görmektedir. Yazma, bilgiye ulaşılması ve ulaşılan bilginin ifade bulması ile ilintili aşamalardan meydana gelen bir beceridir (Carter vd., 2002). Nunan (2003)'da yazma becerisini duygu, düşünce ve fikirlerin okuyucuya kelimeler, cümleler ve de paragraflar aracılığıyla aktarılması şeklinde ifade etmektedir.

Yazma becerisi insanların iletişim kurma ile ilgili ihtiyaçlarını karşılamasının yanı sıra insanların diğer öğrenme süreçlerine de katkı sağlar. Bireylerin yazma becerilerinin gelişmesiyle aynı zamanda onların yazma konusu ile ilgili sahip oldukları bilgileri uygulamaları ve bu konuda kendilerini geliştirmeleri sağlanmış olur. Bununla birlikte bireyin yazma becerisinin gelişmesi onun düşünce dünyasını da kontrol edebilmesi anlamına gelir. Bu şekilde birey zihnini aktif bir biçimde kullanır ve bireyin öğrenme süreci daha etkili, verimli bir hale gelir (Raimes, 1983).

Kuvanç (2008:536) da yazmanın dil öğretimine katkısını "Yazma, bir dil becerisi olmanın yanında; bir araya getirme, planlama, dönüştürme, gözden geçirme gibi bilişsel kontrol gerektiren adımları içeren ve üst düzey düşünmeyi sağlayan bir etkinliktir" şeklinde belirtmektedir. Torrance (2012)'a göre ise yazma bir dizi bilişsel süreç, bilgiyi anlamlandırma mekaniği, kelime, söz dizimi, heceleme ve el hareketi içeren karmaşık bir olgudur.

Yukarıda alan yazında da belirtildiği üzere karmaşık bir süreç olan yazmayı, bireyin etkin ve verimli kullanıp daha kolay anlamlandırabilmesi ve planlayabilmesi için yardım alabileceği en önemli unsur kelimelerdir. Kelimeler aracılığı ile bireyin kendisi ve etrafındaki unsurlar ile bağlantılı tüm düşüncelerini paylaşması kolaylaşacaktır. Özetle, birey kendi iç dünyasını kelimeler vasıtası ile aktarır ve dış dünyayı da kelimeler aracılığı ile algılar ve de anlamlandırır.

$\mathrm{Bu}$ sebeple öğrenim sürecinde kelimeler, üzerinde önemle durulması gereken hususlardan biridir. Budak (2002) kelime edinimi ile ilgili olarak "Türkçenin öğretilmesinde öğrencilere dört temel becerinin kazandırılması hedeflenmektedir. Ancak öğrencilere bu becerilerin verilebilmesi için bazı ön koşul edinimlere gereksinim vardır. Söz konusu olan bu ön koşullardan bir tanesi de öğrencilerin kelime bilgilerinin geliştirilmesidir" ifadelerini kullanmaktadır.

Dil öğretiminin en önemli basamaklarından biri de kelime öğretimidir. Alan yazında kelime kavramı çok çeşitli şekilde tanımlanmaktadır. Kelime, bir ya da birden fazla ses biriminin oluşturduğu yazıda iki boşluğun arasında yer alan, anlamlı bir birimden oluşan, ifadede belli bir biçimsel birlik sunan farklı dizimsel kullanımlarda biçim olarak değişmeyen veya bir kısmı ile değişim sergileyen ses ya da sesler öbeğidir (Vardar, 1998; Korkmaz, 1992; Kantemir, 1997; Ergin, 2005). Carter (1998:5) kelimenin tanımını konuşma ve yazma vasıtası ile bireyin belirli kavramları yansıtmasına eşlik eden ve dilin en anlamlı ögesidir ifadelerini kullanarak yapmıştır. Bununla birlikte Doğan (2014) da kelimeleri bir dilin en temel unsuru olarak ifade etmektedir. Kelimeler, bireyin en basit isteğinden en karmaşık hislerini ve fikirlerini aktarması konusunda yardım aldığı unsurlardandır. Bu nedenle dil öğretiminin temeli olarak "kelimeleri" kabul edebiliriz ifadelerini kullanmıştır. Tüm bu tanımlardan da yola çıkarak kelimeler dört temel dil becerisi de düşünüldüğünde bir dilin öğretiminde olmazsa olmaz kabul edilen ön edinimlerin arasında yer almaktadır. Örneğin, yazma becerisi ele alındığında Tribble (1996) "yazarın daha etkileyici bir biçimde yazabilmesi için dört farklı bilgi çeşidine sahip olması gerekmektedir. Bu bilgiler, içerik bilgisi, bağlam bilgisi, yazma aşamaları ile ilgili bilgi ve kelime bilgisidir" ifadelerini kullanmaktadır. 
Tüm dillerde kullanım bakımından diğer kelimelere oranla daha fazla ön planda olan kelimeler mevcuttur. Yaygın olarak kullanılan bu kelimeler söz konusu olan dili kullanan bireylerin eğitim seviyelerinden, içinde bulundukları sosyal ve ekonomik ortamlardan ve daha birçok unsurdan etkilenmektedirler. Bununla birlikte dil edinimi konusunda Avrupa Dilleri Ortak Çerçeve Programı (CEFR) yol gösterici niteliktedir. Avrupa Dilleri Ortak Çerçeve Programı "Avrupa ülkelerinde dil öğretim programlarını, program yönergelerini, sinav ve ders kitapları vb. konularındaki çalışmaları yönlendirmek için ortak bir çerçeve sunmayı hedeflemektedir. Yabancı dil öğrenenlerin, bu dili iletişim kurmada kullanabilmek için neleri bilmeleri ve bu dilde etkinlik kazanmak için hangi bilgi ve yeteneklerini geliştirmeleri gerektiğini kapsamlı bir biçimde ifade etmektedir. Bu açılamalar hem dillerin kurulmuş olduğu kültür bağlamını hem de yabancı dil öğrenenlerin gerçekleştireceği ilerlemenin, öğrenmenin her aşamasında ve hayat boyu öğrenme temeliyle ölçülebilmesini sağlayan dil yeterlilik seviyelerini kapsamaktadır (Council of Europe, 2002). Bu kapsam çerçevesinde, dil öğreniminde bireylerin gelişmelerine destek olabilecek yeterlilik seviyelerinin ve dil becerilerinin tanımlayıcı bir çizelgesi hazırlanmıştır. Avrupa Dilleri Ortak Çerçeve Programında dil düzeyleri; A1-A2 temel seviye, B1-B2, orta seviye ve C1-C2 ise ileri seviyedir. Her seviye kendisinden sonraki dil seviyesine temel oluşturmaktadır. Dil seviyelerinin sadece dil öğrenen bireyler tarafından değil aynı zamanda kapsamlı bir biçimde öğreticiler tarafından da iyi bilinmesi hususu oldukça önemlidir. Çünkü dil öğretimi süreci içerisinde bireylerin seviyelerine uygun olarak dil becerileri ve kelime öğretimi yapılmalı ki öğrenciler bir adım sonraki seviyeye iyi ve donanımlı bir biçimde hazırlanmış olsunlar. Bu doğrultuda çalışma kapsamında yer alan orta düzey ya da diğer bir ifade ile ara düzey kullanıcı olan B1 seviyesi için "açık ve standart bir dil kullanıldığında iş, okul, eğlence, vb. gibi bildik şeyler hakkındaki ana konuları anlayabilir. Dilin konuşulduğu ülkede seyahat ederken ortaya çıkabilecek sorunların üstesinden gelebilir. Bildik ya da ilgi alanına giren konularla bağlantılı metin üretebilir. Tecrübelerini, olayları, hayallerini, umutların ve hedeflerini anlatabilir, görüşlerini ve planlarının sebeplerini kısaca açıklayabilir" ifadeleri kullanılmıştır (CERF, 2002). Kelimeler bazında program incelendiğinde ise B1 seviyesi için "Aile, hobi, ilgi alanı, iş, gezi, güncel olaylar gibi birçok kendi günlük hayatından konu hakkında, zaman zaman başka kelimeler ile anlatsa da kendini ifade edebilmek için yeterli genişlikte bir kelime bilgisine sahiptir" ifadesi kullanılmıştır (CERF, 2002). Bu kapsamda yabancı dil öğretiminde önemli bir yer teşkil eden kelime çalışmaları da Avrupa Dilleri Ortak Çerçeve Programı dikkate alınarak yürütülmesi gereken çalışmalardandır.

Bununla birlikte çalışmanın önemli kavramlarından biri olan "kelime sıklığının" tanımını yapabilmek için Ölker (2011:16)' in "kelime sıklığı, bir dilde kullanılan ve kelimelerin birbirlerine oranla kullanım sıklığını tespit eden çalışmalardır" ifadelerinden yararlanılabilir. Vardar (2002:174) kelime sıklı̆ını, "belirli bir uzunlukta bir konuşma veya bir yazıda aynı birimin gerçekleşme sayısı olarak" ifade etmiştir. Thorndike (1921) kelime sıklığını "kelime ne kadar sıklıkla kullanılıyor?" sorusunun yanıtı olduğunu ifade etmektedir. Ölker (2011)'e göre "kelime sıklığı çalışmaları eğitimden, psikolojize, işletmeden dil bilimi çalışmalarına kadar olan geniş bir alanda kullanılmak üzere özellikle dil öğretimi noktasında eğitim alanına yönelik önemli bulgular sunmaktadır."

Ölker (2011:17) kelime sıklığı çalışmalarının önemini şu maddeler altında toplamıştır:

1. Kelime sıklığı çalışmaları ikinci dili öğrenmeye başlayan kişilere başlangıç sürecinde hangi kelimelerin verilmesi gerektiğini tespit eder.

2. Sözlükler oluşturulurken kelimelerin hangi anlamlarının öne çıkması gerektiğinin tespitini yapar.

3. Kapsamlı bir araştırmada temel söz varlığını oluşturan, en fazla kullanılan kelimeler ön plana çıkar.

4. Yapılan çalışmalarda tespit edilen kelimeler sayesinde dilin yaşadığı değişim evreleri tespit edilir. 
5. Tespit edilen kelimelerden hareketle dil kullanıcılarında oluşan kültürel değişim ortaya çıkartılır.

6. Dilde yer alan yabancı kelime oranları belirtilerek dilin gelişimi ile ilintili bilgi aktarımı yapılır.

7. "Stilistik" araştırmalarda detaylı veri elde edilmesini sağlar.

8. Çalışmalar sayesinde metin incelemeleri daha kapsamlı yapılır ve dolayısıyla yorumlar daha fazla detaylandırilır.

Dil öğretiminde kelime sıklığı çalışmalarının önemini Karadüz (2004:1609) de şu şekilde belirtmektedir:

1.Özellikle dil öğretimi ile ilgili yürütülen çalışmalar açısından önem arz eder.

2.Yazılı ve sözlü metinlerin incelenmesi ve bunlarla bağlantılı olarak sözlük oluşturma çalışmalarına katkı sağlar.

3.Veri elde edilmesi bakımından metinlerin araştırılması, dil ve anlatım özelliklerinin tespit edilmesinin alt yapisını hazırlar.

4.Toplumsal dil bilimi, toplum bilimi vs. gibi alanlarda yürütülecek olan çalışmaların alt yapısını oluşturur.

Bu düşünceler doğrultusunda kelime sıklığı çalışmaları, kelime hazinesi ile ilintili yürütülen araştırmaların temelini oluşturur. Tüm dillerde bazı kelimeler diğer kelimelere oranla daha fazla tekrar edilirler. Dilde meydana gelen bu tekrarlar sıklık çalışmalarının yapılmasını önemli ve gerekli kılmıştır (Karadağ, 2005). Onan (2016:23) kelime öğretimi evresinin daha etkili ve bilimsel bir biçimde yürütülebilmesi için kelime sıklığı araştırmalarının verilerine ihtiyaç duyulmaktadır. Kelime sıklı̆̆ 1 ile ilgili yapılan çalışmalar sonucunda ulaşılan veriler sayesinde kelimelerin öğretilmesi aşamasında öncelik sırası tespit edilebilmektedir. Özdemirel (2017:10) bu çalışmalar öğrencilere hangi kelimelerin öncelikli olarak verileceğinin yanı sıra kelimelerin hangi anlamlarının da öğretileceği konusunda bilgi sağlar. Dil öğretiminde öğrencilerin yaş, sınıf ve dil düzeyleri dikkate alınarak sıklık çalışmalarından elde edilen veriler ile kelimelerin gruplandırılması da yapılabilir. Göçen ve Okur (2017:121)'a göre sıklık çalışmaları ile öğrencilerin sahip oldukları kelime hazinesine dairde bilgi edinilmektedir. Ayrıca bu çalışmalar sayesinde farklı demografik özellikleri olan aynı zamanda farklı dil ve sınıf düzeyinde eğitim alan öğrencilerin kelime hazinelerine ilişkin dil özellikleri tespit edilebilmektedir. Bu şekilde öğrencilerin algısal ve üretimsel söz varlıkları da araştırılabilmektedir.

Vardar, Huber, Güz, Öztokat ve Senemoğlu'un Açıklamalı Dilbilim Terimleri Sözlüğü'nde de sıklık çalışmalarının önemi vurgulanmıştır: (2002:175).

"Sıklık, kullanılabilirlik kavramıyla birlikte yabancı dil öğretimi alanında öğretilecek ögelerin belirlenmesine ve aşamalanmasına büyük katkıda bulunmuştur. Yabancı dil öğretimi dışında sözlük çalışmalarının yanı sıra biçembilim incelemelerinde de bu kavramdan geniş ölçüde yararlanılmıştır. Sıklık incelemeleri tüm dil birimlerine uygulanmaktadır: Sesbirimler, sözlükbirimler, sözdizimsel yapılar vb. Dildeki sözcüklerin yazıda ve konuşmada eşit olarak dağ̆lmadığın gözlemleyen, kimi ögelerin diğerlerine oranla daha sık kullanıldığının bilincine varan araştırmacılar, birçok dilde sözcüksel sıklık dizelgeleri oluşturmuşlardır. Bu çalışmalar özellikle dil öğretimi konusunda yararl olmuş, yöntemlerin geliştirilmesini sağlamıştır."

Alan yazındaki kelime sıklığı ile ilgili bu çalışmalar doğrultusunda sıklık çalışmaları sadece ana dil öğretiminde değil aynı zamanda yabancı dil ediniminde de yararlanılabilecek önemli konular arasında yer almaktadır. Aksan (2004:256)'a göre bu tarz kelime sıklık çalışmaları, ilköğretim ve ortaöğretim kitaplarında, yetişkinlerin eğitiminde kullanılan kitaplarda, yabancılar için 
hazırlanacak Türkçe kitaplarında kelimelerin seçimi konusunda yol gösterici olma niteliğini taşımaktadır. Bu açıklamalara ek olarak "Sıklık cetvelleri olmadığı ve kelimelerin kullanılıs sıklığ dikkate alınmadığ doğrultusunda yapıldığın ifade etmektedir. Araştırmacının bu açıklamaları bugün Türkçe öğretimindeki önemli problemlerden birine işaret etmektedir" (Aksan, 2004:256). Bu bağlamda Barın (2003)'a göre de Türkçenin sözvarlığının sağlıklı bir biçimde ortaya çıkartılması ana dili eğitiminde aynı zamanda Türkçenin yabancı dil olarak öğretiminde temel şartlardandır. Çünkü Kılıçarslan ve Bülbül (2016)'e göre yabancı dil olarak Türkçe öğretiminde hangi düzeyde hangi konuların ve kelimelerin öğretiminin yapılacağı noktasında henüz bir uzlaşma sağlanamamıştır.

Kelime ve kelime sıklık çalışmalarının hem ana dili öğretiminde hem de ikinci dil edinimlerinde önemini vurgulayan bu düşünceler ekseninden bakıldığında Türkçe öğretimi araştırmalarında da sıklık çalışmaları yapılmakta ve bu çalışmalardan ulaşılan sonuçlara dayanılarak bazı önerilerde bulunulmaktadır. Bu çalışmalardan bazıları şunlardır: Aksoy (1936), Pierce (1960), Harıt (1971), Çifçi (1991), Kırca (1992), Tosunoğlu (1998), Koçak (1999), Yazı (2005), Yiğittürk (2005), Kurudayığlu (2005), Karadağ (2005), Baş (2006) ve Dolunay'ın (2009) çalışmaları sayılabilir.

Aynı zamanda Türkçenin yabancı dil olarak öğretimi konusunda da yapılmış kelime sıklık çalışmaları mevcuttur. Bu çalışmalar arasında; Açık (2011), Çelik (2014), Arslan ve Durukan (2014), Arslan (2014), Bozkurt (2015), Aydın (2015), Çınar ve İnce (2015), Çiçek (2015), Akbulut ve Yaylı (2015), Şimşek (2015), Göçen ve Okur (2017) yer almaktadır. Bu çalışmalar öğrencilere öğretilen kelimeleri listelemesi açısından oldukça önemlidir fakat öğrencilerin kelime kullanımlarını ve kelime seçimlerini aktarmamaktadır.

Bununla birlikte kelime ve kelime sıklı̆̆ı ile ilgili yapılan çalışmalar oldukça yetersizdir. Bu noktadan hareket ile bu çalışmada aşağıdaki sorulara yanıt aranmıştır.

1. Öğrencilerin yazma çalışmalarında en sık tekrarlanan ilk on beş kelime ve kelime türleri nelerdir?

2. Öğrencilerin yazma çalışmalarında kaç kelime yer almaktadır?

3. Öğrencilerin yazma çalışmalarında kullandıkları temalar arasındaki kelime çeşitliliği nasıldır?

4. Öğrencilerin temalar arası kelime çeşitliliği arasında bir ilişki var mıdır?

5. Öğrencilerin kelime sıklık düzeyleri cinsiyet açısından farklılaşmakta mıdır?

6. Öğrencilerin kelime sıklık düzeyleri milliyetlerine göre farklılaşmakta mıdır?

\section{YÖNTEM}

Araştırmanın bu bölümünde araştırmanın modeli, çalışma grubu, veri toplama araçları, veri toplama süreci, veri analizi, araştırmanın sınırlılıkları, verilerin çözümlenmesi ve raporlanması başlıkları açıklanmıştır.

\section{Araştırmanın Modeli}

Türkçeyi yabancı dil olarak öğrenen B1 seviyesindeki öğrencilerin yazma dersinde gerçekleştirilen yazma çalışmalarında kullandıkları kelime sayısının, kelime türlerinin ve kelime çeşitliliğinin incelendiği bu çalışmada, nicel araştırma desenlerinden betimsel tarama modeli kullanılmıştır. Bu araştırmada araştırmacılar, hali hazırda var olan bir fenomen ya da olguyu olduğu gibi, herhangi bir müdahalede bulunmadan açıklamaya ve betimlemeye çalışırlar. "Tarama modeli, geçmişte veya halen mevcut olan bir durumu var olduğu biçimiyle betimlemeyi 
hedefleyen araştırma yaklaşımıdır. Çalışmaya konu olan olay, kişi veya nesne kendi şartları içinde ve olduğu hali ile tanımlanmaya çalışılır. Onlara karşı herhangi bir etkileme ve değiştirme çabası gösterilmez (Karasar, 2012:77). Atalmış (2019)'a göre ise tarama modelleri; “Günlük yaşamda her alanda karşımıza çıkan tarama alıştırmaları, araştırma yapılan grubun özelliklerini ölçmek veya var olan durumu ortaya çıkarmak için kullanılan tekniklerdir. Tarama alıştırmaları, anket ya da görüşme protokollerine dayanan deneysel olmayan araştırma yöntemi" olarak da tanımlanmaktadır. Bu sebeple bu araştırmada tarama modelinin kullanıldığını söylemek mümkündür. Çalışmada araştırma konusu olan kelime sıklığı ve çeşitliliği sürekli ve oranlı bir yapıya sahip olduğu için bağımlı değişken; cinsiyet ve uyruk bölgeleri ise kategorik değişken yapısında olduğundan bağımsız değişken olarak ele alınmıştır.

\section{Çalışma Grubu}

Araştırmaya 2018-2019 eğitim-öğretim yılında Denizli ili Pamukkale Üniversitesi'nde bulunan Dil Öğretimi Uygulama ve Araştırma Merkezi (PADAM) bünyesinde öğrenim gören 15 yabanc1 uyruklu öğrenci gönüllülük esasına göre katılmıştır. Bu öğrencilerin demografik özelliklerine ilişkin cinsiyet ve uyrukları aşağıdaki tabloda sunulmuştur.

Tablo 1. Araştırmaya Katılan Yabancı Uyruklu Öğrencilerin Cinsiyet ve Uyruk Bilgileri

\begin{tabular}{|l|l|l|}
\hline Öğrenci kodu & Cinsiyet & Uyruğu \\
\hline Ö1 & Erkek & Kamerun \\
\hline Ö2 & Erkek & Filistin \\
\hline Ö3 & Erkek & Nijerya \\
\hline Ö4 & Erkek & Bangladeş \\
\hline Ö5 & Erkek & Yemen \\
\hline Ö6 & K1z & Etiyopya \\
\hline Ö7 & K1z & Makedonya \\
\hline Ö8 & Erkek & Etiyopya \\
\hline Ö9 & Erkek & Komorlar Birliği \\
\hline Ö10 & K1z & Ürdün \\
\hline Ö11 & K1z & Somali \\
\hline Ö12 & Erkek & Çad Cumhuriyeti \\
\hline Ö13 & Erkek & Yemen \\
\hline Ö14 & Erkek & İan \\
\hline Ö15 & K1z & Afganistan \\
\hline
\end{tabular}

Araştırmaya 15 yabancı uyruklu öğrenci katılmıştır. Bu öğrencilerin 5’i kız, 10'u erkektir. Farklı ülkelerden öğrencilerin katıldığı araştırmada Kamerun, Nijerya, Bangladeş, Etiyopya, Komorlar Birliği gibi Afrika ülkelerinden olduğu gibi, Filistin, Yemen, Makedonya, İran gibi çeşitli Ortadoğu ve Avrupa ülkelerinden de öğrencilerin olduğu görülmektedir.

\section{Veri Toplama Araçları}

Yazma dersinde belirli temalar (Hastane, Postane ve Toplu ulaşım) çerçevesinde uygulanan yazma çalışmalarında kullanılan kelime sayısını, kelime türlerini ve kelime çeşitliliğini tespit 
etmek amacını taşıyan çalışmada öğrencilerin demografik özellikleri ile ilgili değişkenleri (cinsiyet, ülke vb.) belirlemek için kişisel bilgi formu kullanılmıştır. Belirlenen temaların hangi alanlar ile ilgili olacağını tespit etmek amacı ile 65 yabancı uyruklu öğrenci ile birebir görüşmeler yapılmıştır. Araştırmacı tarafından gerçekleştirilen bu öğrenci görüşmelerinde öğrencilere Türkiye'ye geldiklerinde hangi sosyal alanlarda güçlükler yaşadıkları sorusu yöneltilmiştir. Öğrenciler ile yapılan görüşmelerden elde edilen yanıtlar doğrultusunda öğrencilerin en fazla zorluk yaşadıklarını paylaştıkları 3 (Hastane, Postane ve Toplu ulaşım) sosyal yaşam alanı tespit edilmiştir. Ayrıca uzman görüşleri alınarak ve öğrenci görüşlerine başvurularak tespit edilmiş olan temalar doğrultusunda da toplam 3 temayı ve 6 haftayı kapsayan yazma çalışmaları planlanmıştır.

\section{Veri Toplama Süreci}

Öncelikle araştırmanın yapılacağı Denizli ili Pamukkale Üniversitesi bünyesinde bulunan Pamukkale Üniversitesi Dil Öğretimi Uygulama ve Araştırma Merkezi'nde ve çalışmanın yapılacağı öğrenci grubundan gerekli izinler alınmıştır. Aynı zamanda merkezde derse giren araştırmacı tarafından ilgili çalışmanın amacı ve kapsamı ile ilgili detaylı bilgiler öğrenciler ile paylaşılmıştır.

Çalışma öncesinde yüz yüze öğrenci görüşmeleri gerçekleştirilerek ve uzman görüşleri alınarak tespit edilen 3 sosyal yaşam alanı (Hastane, Postane ve Toplu ulaşım) ile ilgili araştırmacı tarafından çalışma planlanmıştır. Bu çalışma yazma dersi kapsamında toplam 6 haftalık bir süreç içerisinde her hafta aynı günde ve 45 dakikalık (bir ders saati) zaman aralığında serbest yazma etkinliği uygulanmıştır. Çalışma grubunda yer alan öğrencilere yazma aşamasında yeterli zaman verilmiş olup, uygulama tüm öğrenciler yazma çalışmalarını bitirdikten sonra sonlandırılmıştır.

\section{Veri Analizi}

Öğrencilerin yazma dersi kapsamında oluşturdukları yazma çalışmaları sayfaları, araştırmacı ve alanında uzman akademisyen tarafından farklı zaman aralıklarında incelenerek öğrencilerin uygulamada kullandıkları kelime sayısına ve kelime sıklığına göre tasnif edilmiştir. Çalışma sonucunda öğrencilerin yazma çalışmalarında en çok hangi kelimeleri ve ne sıklıkla kullandıklarının tespiti yapılmıştır.

Çalışma grubunda yer alan öğrencilerin kişisel bilgi formları ve yazma çalışmalarında oluşturdukları kâğıtlardan elde edilen veriler SPSS 25.0 paket programı ile analiz edilmiştir.

\section{Araştırmanın Sınırlılıkları}

Bu çalışma 2018-2019 eğitim-öğretim yılı Pamukkale Üniversitesi Dil Öğretimi Uygulama ve Araştırma Merkezi'nde B1 seviyesinde eğitim gören 15 yabancı öğrenci ve yazma dersinde gerçekleştirilen toplam 6 haftalık bir uygulama süreci ile sınırlıdır.

Çalışmada kelimelerin tespit edilmesine geçilmeden önce hangi kelimelerin kelime sayısı ve kelime sıklık tablosuna dâhil edilip edilmeyecekleri konusunda şu sınırlılıklar temel alınmıştır:

- $\quad$ Bu araştırmada özellikle sıklıkla ifade edilen ilk 15 kelimenin tespiti amaçlamıştır. Dolayısıyla bu sıralamada yer alan kelimelerin dışındaki kelimeler kapsam dışında tutulmuştur.

- $\quad$ Tarihler, rakamlar ve sayılar listeye dâhil edilmemiştir. 
- Yer adı ve kişi adı gibi özel isimler listede yer almamaktadır.

- $\quad$ Ay, yıl ve gün isimleri listede yer almamaktadır.

- Sözlükte madde başı olan kelimeler alınmıştır.

- $\quad$ Belgisiz zamirler ve belgisiz sıfatlar ayrı maddeler dahilinde yazılarak listeye alınmıştır.

\section{Verilerin Çözümlenmesi ve Raporlanması}

Araştırmada elde edilen verilerin çözümlemesi ve raporlanması altı aşamada gerçekleştirilmiştir: (a) yazma çalışmalarının okunması, (b) kelimelerin çalışma yaprağına girilmesi, (c) kelimelerin sayımı, (d) kelimelerin analize hazırlanması, (e) uygun analiz birimine karar verilmesi ve (f) raporlamadir.

(a) Metinlerin okunması: "Hastane", "Postane" ve "Toplu ulaşım" temalarında ikişer tane yazılan toplamda altı yazma çalışması okunmuş; kelimeler gözden geçirilmiş ve irdelenmiştir.

(b) Kelimelerin çalışma yaprağına girilmesi: Yazma çalışmalarında kullanılan kelimelerin okunup incelemesinin ardından, tek bir Excel dosyası içinde her öğrenci için oluşturulan ayrı ayrı çalışma sayfalarına kelimeler birer birer girilmiştir. Toplamda 15 çalışma sayfasında yazma etkinliklerinde yazılan kelimeler kaydedilmiştir.

(c) Kelimelerin sayılması: Çalışma yaprağına yeni kelimeler girildikçe, bu kelimeler sayılmış; tekrarlanan kelimelerin sayısı üzerine eklemeler yapılmıştır.

(d) Kelimelerin analize hazırlanmast: Bu safhaya kadar sadece hangi kelimeden ne kadar geçtiği tespit edilmiştir. Bu işlemin ardından altı farklı etkinlikte geçen kelimeler, bu sefer SPSS programına aktarılmıştır. Bu safhada her etkinlik için bir SPSS dosyası oluşturulmuş; 15 öğrencinin her bir etkinlikte toplamda hangi kelimeyi ne kadar kullandığı ortaya çıkarılmıştır. Örneğin, "Hastane" teması altında birinci yazma aktivitesinde "ev" kelimesini kullanma sayısı 50 olması gibi. 15 öğrencinin verisi tema ve etkinlikler bağlamında bütünleştirilmiştir. Her etkinlik için bir SPSS dosyası oluşturulmuş; veriler bu altı dosya üzerinden ayrı ayrı çözümlenmiş̧tir. Ayrıca, kelime sıklığı ile ilgili araştırma soruları için, öğrencilerin yazdığı her bir yazma çalışmasında bir (1) kere geçen kelime az sıklıkta; iki (2) kere söylenen orta sıklıkta; üç (3) ve yukarısında tekrarlanan kelimeleri ise çok sıklıkta olarak nitelendirilmiştir. Bu kategorilerde sınıflanan kelimeler, sayılmış; ardından SPSS programına girilmiştir.

(e) Uygun analiz birimine karar verilmesi: Bu safhada araştırma sorusunun mantığına dayalı olarak uygun analiz tekniklerine karar verilmiştir. Bu husustan hareketle, birinci, ikinci ve üçüncü araştırma sorularında betimsel istatistiklerden frekans, minimum, maksimum ve aritmetik ortalamalar değerlerinden yararlanılmıştır. Dördüncü, beşinci ve altıncı araştırma sorularında ilişkisel ve farklılaşma durumları ele alındığı için, ayrıca ele alınan hedef kitlenin 30'un altında bir örneklem sayısını içerdiğinden parametrik olmayan testlerin kullanılmasına karar verilmiştir. Dolayısıyla, dördüncü araştırma sorusunda Spearman Korelasyon analizi; beşinci ve altıncı sorularda ise Mann Whitney $U$ testleri gerçekleştirilmiştir.

(f) Raporlama: Son aşamada, araştırma sorularına göre seçilen veri analiz tekniklerinin doğası ve mantığına uygun tablolaştırma biçimleri ve analiz birimlerine göre ulaşılan sonuçlar, gerekçeleri ile açıklanmış ve yorumlanmıştır. 


\section{BULGULAR}

Bu bölümde altı araştırma sorusundan hareketle sırasıyla çözümlenen ve yorumlanan araştırma bulgularına yer verilmiştir. Öğrencilerin oluşturdukları yazma çalışmalarında sıklıkla tekrarlanan kelime ve kelime türleri nelerdir? Sorusunu yanttlamak için üç farklı tema için yazılan ikişer yazma çalışmasında geçen kelimeler sayılmıştır. Bu sayma işlemi sonucunda aşağıdaki matris oluşturulmuştur.

Matris incelendiğinde, öncelikle "Hastane" teması altında yazılan iki yazma etkinliği sonrasında özellikle "ve" ile "sonra" bağlaçları sıkça kullanılan kelimeler arasında olduğu gözlenmiştir. Bunları sırasıyla tema ile yakından ilişkili olan "doktor" ve "hastane" kelimeleri takip etmiştir. Öğrencilerin ifadeleri doğrultusunda iki çalışmada da en fazla kullanılan eylem ise "git-" olarak karşımıza çıkmaktadır. "Doktor" ve "hastane" gibi kelimelerin yanı sıra özellikle birinci yazma çalışmasında "hastane" teması ile ilişkili "ilaç", "hemşire" ve "reçete" gibi olgusal kavramlar ön plana çıkmıştır. Diğer yandan ise, daha çok "randevu almak", "aile hekimi" ve "iğne" gibi temaya özgü terimlerden sıkça söz edilmiştir. Ayrıca, "çok" kelimesi de yine bu temada yazılmış çalışmalarda sıkça ifade edilen sıfatlardandır. Dahası bu iki çalışmada en fazla söylenen kelime de "arkadaş" tır. Yabancı uyruklu öğrencilerin "Hastane" teması kapsamında yazdıkları iki çalışmada genel itibariyle sağlık sorunlarından hareketle ya arkadaşları ile ya da arkadaşları için hastaneye çokça gidip geldikleri, ilaç, iğne vs. ile doktor ya da hemşireler tarafından tedavi gördüklerine dair bir ana fikrin çıkarılması mümkündür.

"Postane" teması altında yazılan çalışmalarda yine "ve" bağlacının iki yazma çalışmasında da en fazla belirtildiği görülmektedir. Daha sonra her iki çalışmada da sıfat olarak sıkça yazılan "bir" kelimesi gelmektedir. Benzer şekilde, bu temada da "sonra" ve "git" bağlaçları "ve" den sonra en fazla yazılan kelimeler arasındadır. Ayrıca, bu tema kapsamında özellikle birinci çalışmada sıkça tekrarlanan kelimeler arasında "yazmak", "gönder", "kargo", "sıra", "kimlik kartı" ve "adres" gibi olgusal terimler sıralanmıştır. Diğer taraftan, ikinci çalışmada ise, "para" ve "hediye" gibi temaya özgü sözcükler olarak belirtilmiştir.

Son olarak, "Toplu ulaşım" temasında sıkça belirtilen kelime sıralamasına baktığımızda "otobüs" ve "uçak" gibi ulaşım araçları sözcüklerine rastlanmıştır. Daha sonra "ve" ile "sonra" bağlaçları ve "git-" fiili en çok tekrarlanan sözcükler arasındadır. Dahası, diğer temaların dışında "bir" sıfatının yaygın bir şekilde kullanıldığı görülmektedir. Aynı tema altında ilk yazma çalışmasında "otobüs" kelimesine ek olarak "şoför", “bavul”, “bilet", "otogar", "para” gibi olgusal terimlerden sıkça bahsedilmiştir. İkinci çalışmaya baktı̆̆ımızda ise spesifik olarak "taksi", "koltuk", "havalimanı" gibi olgusal terimler göze çarpmaktadır. "Bilet" kelimesi her iki yazma çalışmasında ortak kelime olarak yer bulmuştur.

Tabloya dikkatli bir şekilde baktığımızda üç ayrı temada ortak bir şekilde sıkça kullanılan kelimelerin aynı şekilde renklendirildiği görülecektir. Bulgulara göre önce "ve" bağlacı, daha sonra "sonra" bağlacı üç ayrı temada ortak olarak en fazla dile getirilen kelimeler arasındadır. Ardından "git-" kelimesi üç tema altında altı yazma çalışmasında da ifade edilen eylem olarak karşımıza çıkmaktadır. Ayrıca "bir" sıfatı da sadece "Hastane" adlı temanın birinci yazma çalışmasının dışındaki tüm yazma çalışmalarında sıkça bahsedilen yaygın kelimelerdendir. Benzer biçimde, "o" kelimesi de tüm çalışmalarda olmasa da her üç temada da yoğun bir şekilde söylenen bir sıfat ya da zamirdir. Dahası, son olarak, "al-" fiili de sıklıkla kullanılan ilk on beş kelime arasından üç temada da yer bulan bir kelimedir.

İkinci araştırma sorusunda yabancı uyruklu öğrencilerin üç temada yazma aktivitelerinde kullandıkları kelime miktarının ne olduğu sorgulanmaktadır. Bu soru doğrultusunda her çalışmada geçen kelimeler sayılmış; öğrencilerin her bir çalışmada kullandığı minimum, 
maksimum ve ortalama kelime sayısı ile standart sapma değerlerini yansıtan betimleyici bir tablo oluşturulmuştur.

Tablo 2. Yabancı Uyruklu Öğrencilerin Yazma Çalışmalarında En Fazla Kullanılan İlk 15 Kelime ve Kelime Sıklık Sayıları

\begin{tabular}{|c|c|c|c|c|c|c|c|c|c|c|c|}
\hline \multicolumn{4}{|c|}{ Tema: hastane } & \multicolumn{4}{|c|}{ Tema: postane } & \multicolumn{4}{|c|}{ Tema: toplu ulaşım } \\
\hline \multicolumn{2}{|c|}{ Etkinlik 1} & \multicolumn{2}{|l|}{ Etkinlik 2} & \multicolumn{2}{|c|}{ Etkinlik 1} & \multicolumn{2}{|c|}{ Etkinlik 2} & \multicolumn{2}{|c|}{ Etkinlik 1} & \multicolumn{2}{|l|}{ Etkinlik 2} \\
\hline Kelime & Sayı & Kelime & Say 1 & Kelime & Say1 & Kelime & Say1 & Kelime & Say1 & Kelime & Say1 \\
\hline ve & 50 & sonra & 38 & ve & 43 & ve & 53 & otobüs & 39 & uçak & 44 \\
\hline sonra & 45 & o & 36 & yaz & 30 & bir & 48 & git- & 34 & ve & 29 \\
\hline doktor & 40 & git & 34 & bir & 29 & para & 44 & ve & 29 & çok & 28 \\
\hline hastane & 32 & ve & 31 & mektup & 27 & gönder- & 38 & sonra & 22 & git- & 27 \\
\hline gün & 24 & hastane & 30 & sonra & 27 & sonra & 35 & al & 21 & sonra & 27 \\
\hline Git- & 23 & doktor & 22 & gönder- & 21 & git- & 35 & güzel & 18 & hin & 25 \\
\hline çok & 21 & 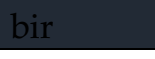 & 21 & git- & 20 & baba & 34 & bir & 17 & taksi & 24 \\
\hline oda & 21 & var & 19 & kargo & 19 & 0 & 33 & kalk- & 17 & koltuk & 24 \\
\hline ilaç & 20 & $\begin{array}{l}\text { randevu } \\
\text { almak }\end{array}$ & 19 & ben & 19 & ben & 32 & şoför & 16 & o & 19 \\
\hline arkadaş & 19 & $\begin{array}{l}\text { aile } \\
\text { hekimi }\end{array}$ & 17 & o & 18 & için & 27 & bavul & 16 & bin & 18 \\
\hline hemşire & 18 & iğne & 16 & çok & 16 & çok & 26 & bilet & 16 & bilet & 16 \\
\hline gel- & 17 & söyle & 15 & için & 16 & hediye & 25 & otogar & 15 & gün & 15 \\
\hline reçete & 17 & al- & 14 & sira & 15 & kargo & 23 & para & 15 & çağır- & 15 \\
\hline Al- & 17 & çok & 14 & $\begin{array}{l}\text { kimlik } \\
\text { kartı }\end{array}$ & 14 & al- & 23 & için & 14 & havalimanı & 15 \\
\hline hasta & 14 & arkadaş & 14 & adres & 14 & bu & 21 & bekle- & 14 & ben & 15 \\
\hline
\end{tabular}

Tablo 3. Yabancı Uyruklu Öğrencilerin Tema ve Etkinliklere Göre Yazma Çalışmalarında Kullandıkları Kelime Sayılarına İlişkin Min., Max, Ortalama Değerler

\begin{tabular}{|c|c|c|c|c|c|c|}
\hline Tema & Etkinlik & $\mathrm{N}$ & Minimum & Maksimum & Ortalama & Genel ortalama \\
\hline \multirow{2}{*}{ Hastane } & Etkinlik 1 & 15 & 35,00 & 164,00 & 78,33 & \multirow{2}{*}{73,8} \\
\hline & Etkinlik 2 & 15 & 37,00 & 158,00 & 69,27 & \\
\hline \multirow{2}{*}{ Postane } & Etkinlik 3 & 15 & 40,00 & 100,00 & 61,13 & \multirow{2}{*}{69,47} \\
\hline & Etkinlik 4 & 15 & 42,00 & 206,00 & 77,80 & \\
\hline \multirow{2}{*}{ Toplu ulaşım } & Etkinlik 5 & 15 & 19,00 & 80,00 & 47,93 & \multirow{2}{*}{49,8} \\
\hline & Etkinlik 6 & 15 & 28,00 & 90,00 & 51,67 & \\
\hline
\end{tabular}


Tabloya baktığımızda yabancı uyruklu öğrencilerin toplu ulaşım hakkında yazmış oldukları iki yazma çalışmasında yer kelime sayısının diğerlerine nispeten daha az olduğu dikkat çekmektedir. "Hastane" temasında yazılan iki çalışmada ise özellikle minimum ve maksimum kelime sayılarının birbirine yakın ve yüksek seviyede olması nedeniyle ortalama kelime sayısının en fazla olduğu bu temadır. "Postane" temasında özellikle ikinci çalışmada maksimum kelime sayısında önemli bir artış olsa da birinci çalışmaya nispeten daha az sayıda kelime kullanıldığından ortalama kelime sayısındaki dengeyi düşürmüştür. Bu sebeple, genel ortalama kelime sayısı en fazla "Hastane", daha sonra "Postane" ve "Toplu ulaşım" şeklinde sıralanmıştır.

Üçüncü araştırma sorusunda da yabancı uyruklu öğrencilerin yazma çalışmalarında belirtilen kelimelerin çeşitliliği nasıldır? ifadesine yanıt aranmaktadır. Bu sorudan hareketle, çalışmalarda geçen en az bir kez söylenen çeşitli kelime ya da kelime türleri sayılmış; öğrencilerin her bir yazma çalışmasında kullandığı minimum, maksimum ve ortalama çeşitli kelime sayısı ile genel ortalama kelime sayısını gösteren tabloda aşağıdaki gibidir.

Tablo 4. Yabancı Uyruklu Öğrencilerin Tema ve Etkinliklere Göre Yazma Çalışmalarında Kullandıkları Çeşitli Kelime Sayılarına İlişkin Min., Max, Ortalama Değerler

\begin{tabular}{lcccccc}
\hline Tema & Etkinlik & $\mathrm{N}$ & Minimum & Maksimum & Ortalama & Genel ortalama \\
\hline \multirow{2}{*}{ Hastane } & Etkinlik 1 & 15 & 24,00 & 91,00 & 44,07 & 43,57 \\
& Etkinlik 2 & 15 & 24,00 & 91,00 & 43,07 & \\
\multirow{2}{*}{ Postane } & Etkinlik 3 & 15 & 28,00 & 59,00 & 40,53 & 45,37 \\
& Etkinlik 4 & 15 & 25,00 & 112,00 & 50,20 & \\
\multirow{2}{*}{ Toplu ulaşım } & Etkinlik 5 & 15 & 15,00 & 59,00 & 35,93 & \multirow{2}{*}{ Etkinlik 6 } \\
& & 15 & 21,00 & 62,00 & 39,33 & \\
\hline
\end{tabular}

Tabloda görüldüğ̈̈ üzere, yabancı uyrukların öğrencilerin kullandığı çeşitli kelime sayısı bakımından en düşük kelime çeşitliliğinin toplu ulaşım temasında yazılan çalışmalarda olduğu anlaşılmaktadır. "Postane" temasına baktığımızda ise, özellikle ikinci temada zengin bir kelime yığınından dolayı farklı kelimelerin kullanılması kelime çeşitliliğinin en fazla oluşmasına katkı sağladığı söylenebilir. Son olarak, bir önceki araştırma sorusunda saptanan bulgularda da bahsedildiği üzere, "Hastane" teması yazılan kelime sayısının en çok olduğu temaydı. Ancak kelime çeşitliliği açısından "Postane" temasının altındadır. Bunun nedeni "Hastane" temasında birbirini tekrarlayan kelimelerin sıklığının daha fazla oluşuna bağlanmaktadır.

Yabancı uyruklu öğrencilerin üç ayrı temada ikişer tane oluşturmuş oldukları yazma çalışmaları arasındaki kelime çeşitliliği bakımından bir ilişki olup olmadığını anlamak için bir korelasyon analizi gerçekleştirilmiştir. Bu analize ait korelasyon katsayıları aşağıdaki gibidir.

Korelasyon analizine bakıldığında, "Hastane" teması kapsamında yazılan birinci yazma çalışması ile aynı temada yazılan ikinci çalışmada geçen kelime çeşitliliği arasında anlamlı bir ilişki olduğu ortaya çıkmıştır ( $r h o=, 532, \mathrm{p}<.05)$. Bu bulgudan hareketle, "Hastane" teması altında yazılan iki çalışmada kullanılan farklı kelime sayılarının aslında birbirine yakın olduğu söylenebilir. Yani, aynı temada bir etkinlikte kullanılan kelime sayısı arttıkça, o tema altında yazılan kelime sayısının çeşitliliğinin de artış göstereceğini ifade etmek mümkündür. Aynı şekilde, "Hastane" temasının ikinci etkinliği ile "Postane" temasında gerçekleştirilen iki yazma aktiviteleri arasında kullanılan çeşitli kelime sayılarında anlamlı, pozitif bir ilişki olduğu göze 
çarpmaktadır (rho=.674; rho=.644; $\mathrm{p}<.05$ ). Özellikle, bu iki temada yabancı uyruklu öğrenciler "Hastane" ve "Postane" mekânlarında benzer ya da yakın süreç, işlem ve hareketleri geçirmiş olduklarından, yazma çalışmalarında kullandıkları kelimelerin çeşitliliği de aynı şekilde benzerlik gösterdiği sonucuna varılabilir. Dahası, "Hastane" temasındaki etkinlikler arasındaki çeşitli kelime kullanma bulgularında olduğu gibi, "Postane" ve "Toplu ulaşım" temalarındaki iki yazma etkinliği de kelime çeşitliliği açısından birbiriyle benzerlik gösterdiği bulunmuştur $(\mathrm{rho}=.694 ; \mathrm{rho}=.661 ; \mathrm{p}<.05)$. Diğer taraftan, "Postane" temasında yazılan ikinci yazma çalışması ile toplu ulaşım temasındaki ikinci yazıma etkinliğinde kullanılan çeşitli kelime sayısı bakımından birbiriyle yakından ilişkilidir ( $\mathrm{rho}=.531, \mathrm{p}<.05)$. Bunun sebebi, Tablo 5 'te özellikle "Postane" temasının ikinci etkinliğinde kullanılan kelime çeşitliliği miktarındaki önemli bir artıştan kaynaklandığı söylenebilir.

Tablo 5. Yabancı Uyruklu Öğrencilerin Tema ve Etkinlikler Arası Gözlenen Çeşitli Kelime Sayıları Arasındaki İlişkilere Dair Korelasyon Analizi Sonuçları

\begin{tabular}{lrrrrrc}
\hline Tema - etkinlik & e1 & e2 & e3 & e4 & e5 & e6 \\
\hline Hastane - e1 & 1,000 & & & & & \\
Hastane - e2 &, $532^{*}$ & 1,000 & & & & \\
Postane - e3 &, 349 &, $674^{* *}$ & 1,000 & & & \\
Postane - e4 &, 472 &, $644^{* *}$ &, $694^{* *}$ & 1,000 & & \\
Toplu ulaşım - e5 &, 222 &, 286 &, 208 &, 414 & 1,000 & \\
Toplu ulaşım - e6 &, 151 &, 473 &, 362 &, $531^{*}$ &, $661^{* *}$ & 1,000 \\
\hline
\end{tabular}

Beşinci araştırma sorusunda Yabancı uyruklu öğrencilerin kelime sıklık düzeylerinin cinsiyete göre farklılaşma durumuna yanıt aranmıştır. Bu sorudan hareketle Mann Whitney U testi yapılmış; bu teste ait sonuçlar, Tablo 6'da gösterilmiştir.

Tablo 6' daki Mann Whitney U testi sonuçları, yabancı uyruklu öğrencilerin yazma çalışmalarında geçen kelimelerin tekrarlanma sıklığının cinsiyete göre anlamlı bir şekilde farklılaşmadığını açılamaktadır ( $\mathrm{p}>$.05). Yalnızca, "Postane" teması bağlamında yazılan ikinci çalışmada çok sıklıkta tekrarlanan kelime sayısının cinsiyet açısından anlamlı bir şekilde farklılaştığ görülmektedir [U (15) =8,000; p<.05]. Bu sonuca göre, kız öğrencilerin çok sıklıkta kullandıkları kelime sayısının erkeklerden fazla olduğu görülmüsştür.

Son araştırma sorusunda Yabancı uyruklu öğrencilerin kelime sıklık düzeylerinin milliyetlerine göre farklılaşıp farklılaşmadığını anlamak için Mann Whitney U testi yapılmıştır. Bu teste ait sonuçlar, aşağıdaki tablodaki gibidir. 
Tablo 6. Yabancı Uyruklu Öğrencilerin Kelime Sıklık Düzeylerinin Cinsiyete Göre Farklılaşma Durumuna İlişkin Mann Whitney U Testi Sonuçları

\begin{tabular}{|c|c|c|c|c|c|c|c|c|}
\hline & & Cinsiyet & $\mathrm{N}$ & Ortalama sirası & Siralar toplamı & $\mathrm{Z}$ & $\mathrm{U}$ & $\mathrm{p}$ \\
\hline \multirow{9}{*}{ 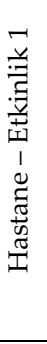 } & \multirow{3}{*}{$\mathrm{Az}$} & Erkek & 10 & 6,90 & 69,00 & & & \\
\hline & & $\mathrm{K} 1 \mathrm{z}$ & 5 & 10,20 & 51,00 & $-1,358$ & 14,000 & ,174 \\
\hline & & Toplam & 15 & & & & & \\
\hline & \multirow{3}{*}{ Orta } & Erkek & 10 & 7,15 & 71,50 & & & \\
\hline & & $\mathrm{K} 1 \mathrm{Z}$ & 5 & 9,70 & 48,50 & $-1,056$ & 16,500 & 291 \\
\hline & & Toplam & 15 & & & & & \\
\hline & \multirow{3}{*}{ Çok } & Erkek & 10 & 8,20 & 82,00 & & & \\
\hline & & $\mathrm{K} 1 \mathrm{z}$ & 5 & 7,60 & 38,00 &,- 248 & 23,000 & 804 \\
\hline & & Toplam & 15 & & & & & \\
\hline \multirow{9}{*}{ 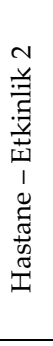 } & \multirow{3}{*}{$\mathrm{Az}$} & Erkek & 10 & 7,35 & 73,50 & & & \\
\hline & & $\mathrm{K} 1 \mathrm{z}$ & 5 & 9,30 & 46,50 &,- 797 & 18,500 & 426 \\
\hline & & Toplam & 15 & & & & & \\
\hline & \multirow{3}{*}{ Orta } & Erkek & 10 & 7,35 & 73,50 & & & \\
\hline & & $\mathrm{K}_{1 \mathrm{z}}$ & 5 & 9,30 & 46,50 &,- 806 & 18,500 & 420 \\
\hline & & Toplam & 15 & & & & & \\
\hline & \multirow{3}{*}{ Çok } & Erkek & 10 & 7,70 & 77,00 & & & \\
\hline & & $\mathrm{K}_{1 z}$ & 5 & 8,60 & 43,00 &,- 370 & 22,000 & 711 \\
\hline & & Toplam & 15 & & & & & \\
\hline \multirow{9}{*}{ 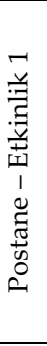 } & \multirow{3}{*}{$\mathrm{Az}$} & Erkek & 10 & 8,55 & 85,50 & & & \\
\hline & & $\mathrm{K} 1 \mathrm{z}$ & 5 & 6,90 & 34,50 &,- 677 & 19,500 & ,499 \\
\hline & & Toplam & 15 & & & & & \\
\hline & \multirow{3}{*}{ Orta } & Erkek & 10 & 8,15 & 81,50 & & & \\
\hline & & $\mathrm{K}_{1 \mathrm{Z}}$ & 5 & 7,70 & 38,50 &,- 558 & 20,500 &, 577 \\
\hline & & Toplam & 15 & & & & & \\
\hline & \multirow{3}{*}{ Çok } & Erkek & 10 & 7,55 & 75,50 & & & \\
\hline & & $\mathrm{K}_{1 \mathrm{Z}}$ & 5 & 8,90 & 44,50 &,- 558 & 20,500 &, 577 \\
\hline & & Toplam & 15 & & & & & \\
\hline \multirow{9}{*}{ 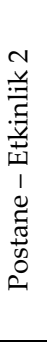 } & \multirow{3}{*}{$\mathrm{Az}$} & Erkek & 10 & 8,85 & 88,50 & & & \\
\hline & & $\mathrm{K}_{1 \mathrm{z}}$ & 5 & 6,30 & 31,50 & $-1,042$ & 16,500 & ,297 \\
\hline & & Toplam & 15 & & & & & \\
\hline & \multirow{3}{*}{ Orta } & Erkek & 10 & 7,65 & 76,50 & & & \\
\hline & & $\mathrm{K} 1 \mathrm{Z}$ & 5 & 8,70 & 43,50 &,- 431 & 21,500 & ,666 \\
\hline & & Toplam & 15 & & & & & \\
\hline & \multirow{3}{*}{ Çok } & Erkek & 10 & 6,30 & 63,00 & & & \\
\hline & & $\mathrm{K} 1 \mathrm{Z}$ & 5 & 11,40 & 57,00 & $-2,107$ & 8,000 & ,035 \\
\hline & & Toplam & 15 & & & & & \\
\hline \multirow{9}{*}{ 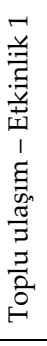 } & & Erkek & 10 & 8,75 & 87,50 & & & \\
\hline & $\mathrm{Az}$ & $\mathrm{K}_{1 \mathrm{Z}}$ & 5 & 6,50 & 32,50 &,- 924 & 17,500 & ,355 \\
\hline & & Toplam & 15 & & & & & \\
\hline & & Erkek & 10 & 7,30 & 73,00 & & & \\
\hline & Orta & $\mathrm{K} 1 \mathrm{z}$ & 5 & 9,40 & 47,00 &,- 864 & 18,000 & ,387 \\
\hline & & Toplam & 15 & & & & & \\
\hline & & Erkek & 10 & 7,30 & 73,00 & & & \\
\hline & Çok & $\mathrm{K}_{1 \mathrm{Z}}$ & 5 & 9,40 & 47,00 &,- 872 & 18,000 & ,383 \\
\hline & & Toplam & 15 & & & & & \\
\hline$N$ & & Erkek & 10 & 7,75 & 77,50 & & & \\
\hline$\stackrel{y}{\exists}$ & $\mathrm{Az}$ & $\mathrm{K} 1 \mathrm{z}$ & 5 & 8,50 & 42,50 &,- 307 & 22,500 & 759 \\
\hline$\stackrel{g}{\square}$ & & Toplam & 15 & & & & & \\
\hline 孛 & & Erkek & 10 & 7,10 & 71,00 & & & \\
\hline$\Xi$ & Orta & $\mathrm{K}_{1 \mathrm{Z}}$ & 5 & 9,80 & 49,00 & $-1,108$ & 16,000 & ,268 \\
\hline$\stackrel{\mathbb{J}^{n}}{=}$ & & Toplam & 15 & & & & & \\
\hline$\Xi$ & & Erkek & 10 & 7,80 & 78,00 & & & \\
\hline है & Çok & $\mathrm{K}_{1 \mathrm{Z}}$ & 5 & 8,40 & 42,00 &,- 254 & 23,000 & 799 \\
\hline F & & Toplam & 15 & & & & & \\
\hline
\end{tabular}


Tablo 7. Yabancı Uyruklu Öğrencilerin Kelime Sıklık Düzeylerinin Milliyetlerine Göre Farklılaşma Durumuna Illişkin Mann Whitney U Testi Sonuçları

\begin{tabular}{|c|c|c|c|c|c|c|c|c|}
\hline & & Uyruk & $\mathrm{N}$ & Ortalama sırası & Siralar toplamı & Z & $\mathrm{U}$ & $\mathrm{p}$ \\
\hline \multirow{9}{*}{ 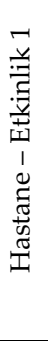 } & \multirow{3}{*}{$\mathrm{Az}$} & Afrika & 6 & 7,67 & 46,00 & & & \\
\hline & & Ortado./Avr. & 9 & 8,22 & 74,00 &,- 238 & 25,000 & 812 \\
\hline & & Toplam & 15 & & & & & \\
\hline & \multirow{3}{*}{ Orta } & Afrika & 6 & 8,83 & 53,00 & & & \\
\hline & & Ortado./Avr. & 9 & 7,44 & 67,00 &,- 598 & 22,000 & ,550 \\
\hline & & Toplam & 15 & & & & & \\
\hline & \multirow{3}{*}{ Çok } & Afrika & 6 & 8,42 & 50,50 & & & \\
\hline & & Ortado./Avr. & 9 & 7,72 & 69,50 &,- 298 & 24,500 & 766 \\
\hline & & Toplam & 15 & & & & & \\
\hline \multirow{9}{*}{ 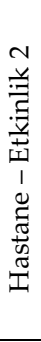 } & \multirow{3}{*}{$\mathrm{Az}$} & Afrika & 6 & 8,00 & 48,00 & & & \\
\hline & & Ortado./Avr. & 9 & 8,00 & 72,00 & ,000 & 27,000 & 1,000 \\
\hline & & Toplam & 15 & & & & & \\
\hline & \multirow{4}{*}{ Orta } & Afrika & 6 & 7,67 & 46,00 & & & \\
\hline & & Ortado./Avr. & 9 & 8,22 & 74,00 &,- 239 & 25,000 & 811 \\
\hline & & Toplam & 15 & & & & & \\
\hline & & Afrika & 6 & 6,25 & 37,50 & & & \\
\hline & \multirow[t]{2}{*}{ Çok } & Ortado./Avr. & 9 & 9,17 & 82,50 & $-1,246$ & 16,500 & ,213 \\
\hline & & Toplam & 15 & & & & & \\
\hline \multirow{9}{*}{ 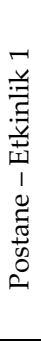 } & \multirow{3}{*}{$\mathrm{Az}$} & Afrika & 6 & 9,83 & 59,00 & & & \\
\hline & & Ortado./Avr. & 9 & 6,78 & 61,00 & $-1,302$ & 16,000 & 193 \\
\hline & & Toplam & 15 & & & & & \\
\hline & \multirow{3}{*}{ Orta } & Afrika & 6 & 8,08 & 48,50 & & & \\
\hline & & Ortado./Avr. & 9 & 7,94 & 71,50 &,- 060 & 26,500 & ,952 \\
\hline & & Toplam & 15 & & & & & \\
\hline & \multirow{3}{*}{ Çok } & Afrika & 6 & 8,50 & 51,00 & & & \\
\hline & & Ortado./Avr. & 9 & 7,67 & 69,00 &,- 358 & 24,000 & 720 \\
\hline & & Toplam & 15 & & & & & \\
\hline \multirow{9}{*}{ 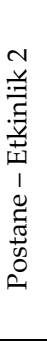 } & \multirow{3}{*}{$\mathrm{Az}$} & Afrika & 6 & 7,67 & 46,00 & & & \\
\hline & & Ortado./Avr. & 9 & 8,22 & 74,00 &,- 474 & 25,000 & ,814 \\
\hline & & Toplam & 15 & & & & & \\
\hline & \multirow{4}{*}{ Orta } & Afrika & 6 & 7,33 & 44,00 & & & \\
\hline & & Ortado./Avr. & 9 & 8,44 & 76,00 &,- 474 & 23,000 & 635 \\
\hline & & Toplam & 15 & & & & & \\
\hline & & Afrika & 6 & 6,58 & 39,50 & & & \\
\hline & \multirow[t]{2}{*}{ Çok } & Ortado./Avr. & 9 & 8,94 & 80,50 & $-1,014$ & 18,500 & ,311 \\
\hline & & Toplam & 15 & & & & & \\
\hline \multirow{9}{*}{ 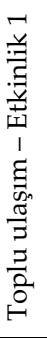 } & & Afrika & 6 & 6,50 & 39,00 & $-1,067$ & 18,000 & 286 \\
\hline & $\mathrm{Az}$ & Ortado./Avr. & 9 & 9,00 & 81,00 & & & \\
\hline & & Toplam & 15 & & & & & \\
\hline & & Afrika & 6 & 7,17 & 43,00 &,- 594 & 22,000 & ,552 \\
\hline & Orta & Ortado./Avr. & 9 & 8,56 & 77,00 & & & \\
\hline & & Toplam & 15 & & & & & \\
\hline & & Afrika & 6 & 8,75 & 52,50 &,- 540 & 22,500 & ,589 \\
\hline & Çok & Ortado./Avr. & 9 & 7,50 & 67,50 & & & \\
\hline & & Toplam & 15 & & & & & \\
\hline$N$ & & Afrika & 6 & 6,08 & 36,50 & & & \\
\hline 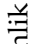 & $\mathrm{Az}$ & Ortado./Avr. & 9 & 9,28 & 83,50 & $-1,358$ & 36,500 & 175 \\
\hline$\frac{7}{x}$ & & Toplam & 15 & & & & & \\
\hline 藏 & & Afrika & 6 & 7,33 & 44,00 & & & \\
\hline$\Xi$ & Orta & Ortado./Avr. & 9 & 8,44 & 76,00 &,- 474 & 44,000 & ,636 \\
\hline$\stackrel{\mathscr{\Xi}}{=}$ & & Toplam & 15 & & & & & \\
\hline ב & & Afrika & 6 & 9,67 & 58,00 & & & \\
\hline$\frac{7}{0}$ & Çok & Ortado./Avr. & 9 & 6,89 & 62,00 & $-1,224$ & 17,000 & 221 \\
\hline$\mapsto$ & & Toplam & 15 & & & & & \\
\hline
\end{tabular}


Tablo 7'de görüldüğü gibi, yabancı uyruklu öğrencilerin yazma çalışmalarında kullandıkları kelime sıklık düzeylerinin uyruklarına göre anlamlı bir değişime neden olmadığı anlaşılmaktadır (p>.05). Buradan hareketle, araştırmaya katılan yabancı uyruklu öğrenciler bağlamında hangi uyruktan olursa olsun, belirtilen kelime sıklık düzeylerinin ayn ya da çok benzer seviyede olduğunu söylemek mümkündür.

\section{TARTIŞMA ve SONUÇ}

Ana dili eğitiminin en önemli becerisi olan yazma becerisi aynı şekilde yabancı öğrencilere Türkçe öğretimi alanında da önemli bir yer teşkil etmektedir. Yazma becerisinin geliştirilmesi noktasında uygulama temelli çalışmalar ve özellikle kelime çalışmaları önemli bir unsur olarak karşımıza çıkmaktadır. Bu açıklamalar doğrultusunda kelime çalışmaları sadece ana dili öğretiminde değil aynı zamanda yabancı dil ediniminde de faydalanılabilecek etkili unsurlar arasındadır. Yabancılara Türkçe öğretimi konusu salt kuramsal yaklaşımlarla değil etkinlik çalışmaları ile de desteklenmesi gereken bir alandır. Bu amaç doğrultusunda yürütülen bu çalışmanın bulgularından hareketle aşağıdaki sonuçlar elde edilmiştir:

Yabancı uyruklu öğrencilerin yazma çalışmalarında en sık tekrarlanan ilk on beş kelime ve kelime türleri nelerdir? alt problemine ilişkin ulaşılan sonuçlarda öğrencilerden "Hastane" teması ile ilgili oluşturmaları istenen yazma etkinliğinde "ve" ile "sonra' bağlaçlarının sıklıkla kullanıldıkları sonucuna ulaşılmıştır. Bununla birlikte hastane teması ile yakından ilişkili olan "doktor" ve "hastane" kelimeleri karşımıza çıkmaktadır. Bu doğrultuda öğrencilerin yazma etkinliklerinde en fazla kullandıkları eylem ise "git-" olmuştur. Aynı zamanda hastane teması altında "ilaç", "hemşire" ile "reçete" gibi kelimelerin kullanıldığ tespit edilmiştir. Bununla birlikte yine tema ile ilintili olarak "randevu almak", "iğne" ve "aile hekimi" kelimeleri sıkça kullanılmıştır. "Çok" sıfatının ve "arkadaş" kelimesinin de öğrenciler tarafından en fazla kullanımı olan kelimeler olduğu sonucuna ulaşılmıştır.

"Postane" teması ile ilgili olarak öğrencilerden istenen yazma etkinliği kapsamında ise "ve" bağlacının çok fazla kullanıldığı tespit edilmiştir. Bu alt tema altında oluşturulan her iki yazma çalışmasında da sıkça kullanılan sıfat ise "bir" olmuştur. Bununla birlikte "ve" bağlacını sıklık olarak "sonra" ve "git-" kelimeleri takip etmektedir. Ayrıca bu temada öğrenciler tarafından kullanımı en çok tercih edilen kelimeler ise sırayla "yazmak", "gönder", "kargo", "sıra", "kimlik kartı", "adres", "para" ve "hediye" gibi temaya özgü kelimelerdir. Crossley ve McNamara (2009)'ın ikinci dili öğrenme sürecinde olan öğrencilerin yazma çalışmalarını inceledikleri araştırmalarında bu öğrenciler tarafından "git-", "gel-" gibi eylem bildiren kelimelerin kullanımının sıklıkla tercih edildiği tespit edilmiştir. Göçen ve Okur (2017)'un yabancı uyruklu öğrencilerin yazılı anlatımlarında kullandıkları kelimelerin kullanım sıklığı ile ilgili çalışmalarının bulguları ile bu çalışmanın bulguları birbirini destekler niteliktedir. Göçen ve Okur (2017: 128)'un çalışmalarında B1 seviyesindeki yabancı uyruklu öğrencilerin yazılı anlatımlarında en fazla kullandıkları 20 kelime arasında "ve", "bir" ve "arkadaş" kelimeleri yer almaktadır. Bununla birlikte Karahan (2008:37)'ın ilk öğretim 5. sınıf öğrencilerinin yazılı anlatımlarındaki kelime servetinin belirlenmesine yönelik çalışmasında öğrencilerin en fazla kullandıkları kelimeler arasında "al-", "git-", "bir", "ve" ile "sonra" kelimelerinin olduğu tespit edilmiştir. Karahan (2008)'ın çalışmasında elde ettiği sonuçları, çalışmanın bulgularını desteklemektedir.

En son etkinliklerde yer alan "Toplu ulaşım" temasında ise en fazla kullanılan "otobüs" ve "uçak" gibi ulaşım araçları kelimeleri karşımıza çıkmaktadır. Aynı şekilde "git-" fiili ile "ve" ve "sonra" bağlaçları en çok tekrarlanan kelimelerdendir. Ayrıca "bir" sıfatının yaygın bir biçimde kullanıldığı sonucuna ulaşılmıştır. Tema ile bağlantılı olarak da yazılı çalışmalarda en fazla 
kullanımı tercih edilen kelimeler ise "şoför", "bavul", "bilet", "otogar", "para", "taksi", "koltuk" ve "havalimanı" kelimeleridir. Özcan (2018)'ın yabancılara Türkçe öğretiminde kelime belirleme çalışmasında öğrencilerin cevapları doğrultusunda oluşturulan kelime sıklık listelerinde "bilet", "şoför" ve "otobüs" kelimeleri liste başında yer almaktadır. Çalışmada elde edilen bulgular bu çalışmanın sonuçları ile birbirini destekler niteliktedir.

Ayrıca üç farklı temada ortak bir biçimde sıkça kullanılan kelimeler "ve" ile "sonra" bağlaçlarıdır. Bununla birlikte "git-" kelimesi üç tema altında yer alan altı yazma çalışmasında da en çok kullanılan kelimedir. "Bir" sıfatı da öğrenciler tarafından sıkça tekrarı yapılan kelimelerden birisi olarak karşımıza çıkmaktadır. Bununla birlikte "o" kelimesi tüm yazma çalışmalarında değilse de üç tema başlığı altında sık bir biçimde kullanılmaktadır. Son olarak "al" fiilinin de ilk on beş kelime arasında üç temada da en fazla yer alan kelime olduğu sonucuna ulaşılmıştır. Kelime sıklık çalışmaları ile ilgili araştırmalar incelendiğinde Bilgiç (2016)'in yüksek lisans tez çalışmasındaki sonuçlar ile yürütülen bu çalışmanın bulguları birbiriyle örtüşmektedir. Bilgiç (2016)'in öğrencilerin yazılı çalışmalarında en çok kullandıkları aktif kelimeleri tespit etmek amacıyla yürüttüğü araştırmasının bulgularında öğrencilerin en sık kullandıkları kelimeler arasında "ve", "bir" ve "sonra" kelimeleri ilk siralarda yer almaktadır. Bununla birlikte "gitmek", "almak", "o" ve "arkadaş" kelimeleri de öğrenciler tarafından çok fazla kullanılan kelime grupları arasında listelenmektedir. Aynı şekilde Başpınar (2008)'ın öğrencilerin aktif kelime serveti üzerine gerçekleştirdiği çalışmanın bulguları ile bu çalışmanın bulguları birbiri ile örtüşmektedir. Başpınar (2008)'ın çalışmasında da "bir" sıfatı öğrenciler tarafından sıklıkla kullanılan kelimeler arasında yer almaktadır. Bununla birlikte bu çalışmadan elde edilen bulgular doğrultusunda "al-", "ve", "o" ve "git-" kelimelerinin de öğrenciler tarafından sıklıkla kullanılan kelimeler arasında olduğu sonucuna ulaşılmıştır.

Çalışmanın ikinci araştırma sorusunda ise yabancı uyruklu öğrencilerin üç tema kapsamında yazma çalışmalarında kullandıkları kelime sayısının ne olduğu araştırılmıştır. Öğrencilerin toplu ulaşım teması altında yazmış oldukları iki çalışmada yer alan kelime sayısının yazmış oldukları diğer çalışmalardaki kelime sayısına oranla daha az olduğu sonucuna ulaşılmıştır. "Hastane" teması ise bu bağlamda yazılan iki çalışmada özellikle minimum ve maksimum kelime sayılarının birbirine yakın ve yüksek seviyede olması sebebiyle ortalama kelime sayısının en fazla olduğu tema olarak tespit edilmiştir. Çalışmada öğrencilerin kullandıkları en fazla kelime sayısının "Hastane" temasında daha sonra da "Postane" ve "Toplu ulaşım" temalarında olduğu sonucuna ulaşılmıştır.

Çalışmada yer alan üçüncü araştırma sorusunda "Yabancı uyruklu öğrencilerin yazma çalışmalarındaki temalar arasında kelime çeşitliliği nasıldır? sorusuna yanıt aranmıştır. Öğrencilerin yazma çalışmalarının incelenmesi sonrasında kullandıkları kelime sayısı açısından en düşük kelime çeşitliliğinin "Toplu ulaşım" temasında olduğu sonucuna ulaşılmıştır. "Postane" teması incelendiğinde özellikle ikinci temada zengin bir kelime yığınından dolayı farklı kelimelerin kullanılması kelime çeşitliliğinin en fazla oluşmasına katkı sağladığı tespiti yapılabilir. Kullanılan kelime çeşitliliği bakımından "Postane" temasının altında yer alan ve kullanılan kelime sayısının en fazla olduğu temanın "Hastane" teması olmasının nedeni olarak bu temada birbirini tekrarlayan kelime sıklığının fazla olması sonucuna ulaşılmıştır.

Çalışmanın bir diğer sorusu da "Yabancı uyruklu öğrencilerin temalar arası kelime çeşitliliği arasında bir ilişki var mıdır?" şeklindedir. Bu sorunun yanıtını alabilmek için yabancı uyruklu öğrencilerin üç farklı tema başlığı altında ikişer tane yazmış oldukları çalışmalar arasındaki kelime çeşitliliği açısından bir ilişki olup olmadığının tespiti için bir korelasyon analizi yapılmıştır. Bu analiz sunucunda "Hastane" teması kapsamında yazılan birinci yazıma etkinliği ile aynı temada yazılan ikinci çalışmada geçen kelime çeşitliliği arasında anlamlı bir ilişki olduğu tespit edilmiştir. Aynı şekilde "Hastane" temasının ikinci etkinliği ile "Postane" temasında 
gerçekleştirilen iki yazma çalışmaları arasında kullanılan çeşitli kelime sayılarında anlamlı, pozitif bir ilişki olduğu sonucuna ulaşılmıştır. Bu bağlamda bu iki temada yabancı uyruklu öğrenciler "Hastane" ve "Postane" mekânlarında benzer ya da yakın süreç, işlem ve eylemleri gerçekleştirmiş olduklarından, kullandıkları kelimelerin çeşitliliğinin de aynı şekilde benzerlik gösterdiği sonucuna varılabilir. Bununla birlikte "Postane" temasında yazılan ikinci yazma etkinliği ile "Toplu ulaşım" temasındaki ikinci yazma etkinliğinde kullanılan çeşitli kelime sayısı bakımından birbiriyle yakından ilişkilidir şeklinde bir sonuca ulaşılmıştır.

Çalışma kapsamında yanıtı aranan bir diğer soruda "Yabancı uyruklu öğrencilerin kelime sıklık düzeyleri cinsiyet açısından farklılaşmakta mıdır?" şeklindedir. Bu soruya yanıt almak için gerçekleştirilen Mann Whitney U testi sonuçlarına göre yabancı uyruklu öğrencilerin yazma çalışmalarında geçen kelimelerin tekrarlanma sıklığının cinsiyete göre anlamlı bir şekilde farklılaşmadığı sonucuna ulaşılmıştır. Bununla birlikte "Postane" teması başlığı altında yazılan ikinci çalışmada çok sıklıkta tekrarlanan kelime sayısının cinsiyet açısından anlamlı bir şekilde farklılaştığı tespit edilmiştir. Bu sonuca paralel olarak kız öğrencilerin çok sıklıkta kullandıkları kelime sayısının erkeklerden fazla olduğu sonucuna ulaşılmıştır. Özçelik (2019)'in yabancı uyruklu öğrencilere kelime öğretimi ile ilgili tez çalışmasında yer alan öğrencilerin son test başarı puanları üzerinde cinsiyet ön test başarı puanları ortak etkisinin anlamlı bir biçimde farklılaşmadığı sonucuna ulaşılmıştır. Aynı şekilde Gülcü (2015)'nün yabancılara Türkçe kelime öğretimi ile ilgili doktora tez çalışmasında cinsiyet değişkeninin etkili bir unsur olmadığ sonucuna varılmıştır.

“Öğrencilerin kelime sıklık düzeyleri milliyetlerine göre farklılaşmakta mıdır? alt problemi ile ilgili ulaşılan sonuçlara göre yabancı uyruklu öğrencilerin yazma çalışmalarında kullandıkları kelime sıklık düzeylerinin öğrencilerin milliyetlerine göre anlamlı bir değişime neden olmadığı tespit edilmiştir. Belirtilen kelime sıklık düzeylerinin aynı seviyede ya da çok benzer düzeyde olabileceği sonucuna ulaşılmıştır.

Çalışmanın sonucunda elde edilen bulgular doğrultusunda yabancı uyruklu öğrencilerin temel dil becerilerini özellikle yazma becerisinin geliştirilmesi için kelime çalışmalarına daha fazla yer verilmesi önerilebilir. Aynı şekilde bu çalışmada yer alan üç ana tema dışında da farklı temalar kapsamında çalışılıp çalışmanın kapsamı genişletilebilir. Bu şekilde öğrencilerin farklı kelime edinimleri sağlanmış olup öğrencilerin gerek eğitim süreçlerinde gerekse yabancı bir ülkede yaşadıkları sosyal alanlar konusunda onlara önemli ve ciddi bir destek sağlayacaktır.

\section{KAYNAKÇA}

Açık, F. (2011). Türkçe öğretimi üzerine yabancı yazarların hazırladığı ders kitaplarında söz dağarcığı ve kültürel unsurlar. IV. Uluslararası Dünya Dili Türkçe Sempozyumu, Muğla Üniversitesi: Muğla.

Akbulut, S., ve Yaylı, D. (2015). Yabancı dil olarak Türkçe öğretimi A1-A2 düzeyi ders kitapları üzerine bir izlence çalışması. Erzincan Üniversitesi Sosyal Bilimler Enstitüsü Dergisi (ERZSOSDE), II, 35-46.

Aksan, D. (2004). Dilbilim ve Türkçe Yazıları. İstanbul: Multilingual.

Aksoy, Ö. Â. (1936). Bir Dili Öğrenmek İçin En Lüzumlu Kelimeler ve Bu Kelimelerin Belirtme Usulü. Gaziantep: Gaziantep Halkevi Dil, Edebiyat, Tarih Şubesi Yayınları.

Arslan, N. (2014). Yabancılara Türkçe Öğretimi Ders Kitaplarında Söz Varlı̆̆ı Unsurlarının İncelenmesi. Yayınlanmamış Yüksek Lisans Tezi. Karadeniz Teknik Üniversitesi, Eğitim Bilimleri Enstitüsü. 
Arslan, N., ve Durukan, E. (2014). Yabancılara Türkçe öğretimi ders kitaplarında söz varlı̆̆1 unsurlarınin incelenmesi. International Journal of Language Academy, 2(4), 47-265.

Atalmış, E. H. (2019). Tarama Araştırmaları, (Ed. Sedat Şen ve İbrahim Yıldırım). Ankara: Nobel Yayınevi.

Aydın, M. (2015). Yabancı Dil Olarak Türkçe Öğretiminde Kullanılan Ders ve Okuma Kitaplarındaki Kelime Sıklığı ve Seviyelere Göre Sözcük Hazinesi Çalışması. Yayınlanmamış Yüksek Lisans Tezi. Gazi Üniversitesi, Eğitim Bilimleri Enstitüsü.

Baş, B. (2006). 1985-2005 Yılları Arasında Çocuk Edebiyatı Sahasında Yazılmış Tahkiyeli Metinlerin Söz Varlığı Üzerine Bir Araştırma. Yayınlanmamış Doktora Tezi. Gazi Üniversitesi, Eğitim Bilimleri Enstitüsü.

Başpınar, O. (2008). Illköğretim 5. Sını Öğrencilerinin Aktif Kelime Serveti Üzerine Bir Araştırma. Yüksek Lisans Tezi, Afyon Kocatepe Üniversitesi, Sosyal Bilimler Enstitüsü.

Bilgiç, M. (2016). Batı Avrupa'da İki Dilli Türk Çocuklarının Yazılı Türkçe Kelime Sıklıkları: Fransa Örneği. Yüksek Lisans Tezi. Sakarya Üniversitesi Eğitim Bilimleri Enstitüsü.

Bozkurt, B. (2015). Türkçenin Yabancı Dil Olarak Öğretiminde Orta Seviye (B1-B2 Düzeyi) Hedef Sözcük Belirleme Çalışması. Yayınlanmamış Yüksek Lisans Tezi. Marmara Üniversitesi, Eğitim Bilimleri Enstitüsü.

Budak, Y. (2000). Sözcük öğretimi ve sözlüğün işlevi. Dil Dergisi, 92, 19-25.

Carter, R. (1998). Vocabulary: Applied Linguistic Perspectives. London: Routledge.

Carter, C., Bishop, J. and Kravits, L. (2002). Key to Effective Learning (3rd Ed.), New Jersey: Printice Hall.

CEFR, (Common European Framework References) (2002). Council of Europe, Common European Framework of Reference for Languages: Learning, Teaching, Assessment Case Studies, Council of Europe, Strasbourg.

Crossley, S. and McNamara, D. (2009). Computational Assessment of Lexical Differences in L1 And L2 Writing. Journal of Second Language Writing, 18, 119-135.

Çelik, S. (2014). Yabancı Dil Olarak Almanca ve Türkçe Öğretimi A1 ve A2 Seviyesindeki Ders Kitaplarında Kullanılan Söz Varlığııın Karşılaştııılması. Yayınlanmamış Yüksek Lisans Tezi. Marmara Üniversitesi, Eğitim Bilimleri Enstitüsü.

Çınar, İ., ve İnce, B. (2015). Türkçe ve Türk kültürü ders kitaplarındaki söz varlığına derlem temelli bir bakış. International Journal of Languages' Education and Teaching, 3(1), 198-209.

Çiçek, M. (2015). Avrupa Dil Programı Sözcük Setleri ile Yabancılara Türkçe Öğretimi Kitaplarındaki Sözcüklerin Karşılaştırılması: Yunus Emre Enstitüsü Türkçe Öğretim Seti A1 Ders Kitabı Örneği. International Journal of Language Academy, 3(2), 216-231.

Çifçi, M. (1991). Bir Grup Yükseköğrenim Öğrencisi Üzerinde Kelime Serveti Araştırması. Yayımlanmamış Yüksek Lisans Tezi. Gazi Üniversitesi Sosyal Bilimler Enstitüsü.

Demirel, Ö. (2004). Yabancı Dil Öğretimi, Dil Pasaportu, Dil Biyografisi, Dil Dosyası. Ankara: Pegem A Yayıncilık.

Doğan, Y. (2014). Yabancılara Türkçe kelime öğretiminde market broşürlerinden yararlanma. Journal of Language and Linguistic Studies, 10(1), 89-98. 
Dolunay, S. K. (2009). Illköğretim İkinci Kademede Zaman Ekleri ve Fonksiyonlarının Öğretimi. Yayımlanmamış Doktora Tezi, Gazi Üniversitesi, Sosyal Bilimler Enstitüsü.

Ergin, M. (2005). Türk Dil Bilgisi. İstanbul: Bayrak Yayınevi.

Göçen, G. ve Okur, A. (2017). Türkçeyi yabancı dil olarak öğrenenlerin yazılı anlatımlarındaki sözcüklerin kullanım sıklığı. Erzincan Üniversitesi Eğitim Fakültesi Dergisi, 19(3), 119-136.

Gülcü, İ. (2015). Yabancı Dil Olarak Mobil Destekli Türkçe Kelime Öğretimi. Doktora Tezi, Çanakkale 18 Mart Üniversitesi, Eğitim Bilimleri Enstitüsü.

Güneş, F. (2007). Türkçe Öğretimi ve Zihinsel Yapılandırma. Ankara: Nobel Yayınları.

Güz, N., Huber, E., Senemoğlu, O. ve Öztokat, E. (2002). Açıklamalı Dilbilim Terimleri Sözlüğü. (Editör: Berke Vardar). İstanbul: Multilingual.

Harıt, Ö. (1971). Kelime Hazinesi Araştırması. Ankara: MEB Planlama Araştırma ve Koordinasyon Dairesi Yayını.

Kantemir, E. (1997). Yazılı ve Sözlü Anlatım. Ankara: Engin Yayınevi.

Karadağ, Ö. (2005). İlköğretim I. Kademe Öğrencilerinin Kelime Hazinesi Üzerine Bir Araştırma. Yayımlanmamış Doktora Tezi, Gazi Üniversitesi, Eğitim Bilimleri Enstitüsü.

Karadüz, E. (2004). Sözcük Sıklığı Çalışmalarının Önemi. V. Uluslararası Türk Dili Kurultayı Bildirileri I, s.1605-1613.

Karahan, A. (2008). Uşak Ulubey İlçesi Köy İlköğretim Okulları 5. Sinıfların Yazılı Anlatımlarındaki Kelime Servetinin Belirlenmesi. Yüksek Lisans Tezi, Afyon Kocatepe Üniversitesi, Sosyal Bilimler Enstitüsü.

Karasar, N. (2012). Bilimsel Araştırma Yöntemi. Ankara: Nobel Yayınları.

Kapar Kuvanç, E. B. (2008). Yaratıcı Yazma Tekniklerinin Öğrencilerin Türkçe Dersine İlişkin Tutumlarına ve Türkçe Dersindeki Başarılarına Etkisi. Yayımlanmamış Yüksek Lisans Tezi, Eylül Üniversitesi, Eğitim Bilimleri Enstitüsü.

Kılıçarslan, R. ve Bülbül, F. (2016). A Study on The Word Frequency in Turkish Education As a Foreign Language. Uluslararası Türkçe Eğitimi ve Öğretimi Dergisi: Kuram ve Uygulama, 1(2), 61-77.

Kırca, N. (1992). İlkokulun Dört ve Beşinci Sinıflarında Türkçe Ĕ̆itimi ve Öğretimi Üzerine Araştırmalar:1 Türkçe Ders Kitapları. Yayımlanmamış Yüksek Lisans Tezi. Gazi Üniversitesi Sosyal Bilimler Enstitüsü.

Koçak, H. (1999). Sağllk Meslek Lisesi Öğrencilerinin Kelime Hazinesi ile İlgili Bir Araştırma. Yayımlanmamış Yüksek Lisans Tezi, Gazi Üniversitesi Sosyal Bilimler Enstitüsü.

Korkmaz, Z. (1992). Gramer Terimleri Sözlüğ̈̈. Ankara: TDK Yayınları.

Kurudayığlu, M. (2005). İlköğretim II. Kademe Öğrencilerinin Kelime Hazinesi Üzerine Bir Araştırma. Yayımlanmamış Doktora Tezi. Gazi Üniversitesi Sosyal Bilimler Enstitüsü.

Nunan, D. (2003). Practical English Language Teaching. USA: McGrawHill Publications. p.88.

Onan, B. (2016). Söz Varlığı Terminolojisi Üzerine Bir Analiz Çalışması. Milli Ĕ̆itim Dergisi, Söz Varlı̆̆ı Özel Sayısı, 210, 11-29.

Ölker, G. (2011). Yazılı Türkçenin Kelime Sıklığı Sözlü̆̆ü̈. Doktora Tezi, Selçuk Üniversitesi, Eğitim Bilimleri Enstitüsü.

Öz, F. (2006). Uygulamalı Türkçe Öğretimi. Ankara: Anı Yayıncılık. 
Özcan, H. Z. (2018). Türkçenin Yabancı Dil Olarak Öğretiminde Temel Seviye İ̧̧in Kelime Belirleme Çalışması. Yüksek Lisans Tezi, Uşak Üniversitesi, Sosyal Bilimler Enstitüsü.

Özçelik, M. (2019). Türkçenin Yabancı Dil Olarak Öğretiminde Aktif Kelime Hazinesinin Geliştirilmesi. Yüksek Lisans Tezi, Uşak Üniversitesi, Sosyal Bilimler Enstitüsü.

Özdemirel, A. Y. (2017). Yabancı Dil Olarak Türkçe ve İngilizce Ders Kitaplarındaki Sözcüklerin Kullanım Sıklığı Bağlamında Değerlendirilmesi. Yüksek Lisans Tezi, İstanbul Üniversitesi, Sosyal Bilimleri Enstitüsü.

Pierce, J. E. (1960). Türkçe Kelime Sayımı. Ankara: MEB Yayım Müdürlüğü Basılı Eğitim Malzemeleri Hazırlama Merkezi.

Raimes, A. (1983). Techniques in Teaching Writing. Oxford University Press, Oxford.

Sever, S. (2004). Türkçe Öğretimi ve Tam Öğrenme. Ankara: Anı Yayıncılık.

Şimşek, N. D. (2015). Yabancılara Türkçe öğretimi ders kitaplarındaki metinlerin ilişkisel söz varlığı açısından değerlendirilmesi. International Journal of Science Culture and Sport (IntJSCS), (Special Issue 3), 809-827.

Thorndike, E. L. (1921). The Teacher's Word Book. Teachers College, Columbia University, New York City.

Torrance, M. (2012). Studies in writing: current trends in European research. Bingley [UK]: Emerald.

Tosunoğlu, M. (1998). İlköğretim Okuluna Başlayan Öğrencilerin Okuma Yazmayı Öğrenmeden Önceki Kelime Serveti Üzerine Bir Araştırma. Yayımlanmamış Doktora Tezi. Gazi Üniversitesi Sosyal Bilimler Enstitüsü.

Tribble, C. (1996). Writing, Oxford: Oxford University Press.

Vardar, B. (1998). Açıklamalı Dil Bilim Terimleri Sözlü̆̆̈̈. İstanbul: ABC Kitapevi.

Vardar, B. (2002). Açıklamalı Dil Bilim Terimleri Sözlüğü. İstanbul: Multilungual Yayınları.

Yazı, Z. (2005). Orta Öğretim 10. Sinıf Öğrencilerinin Kelime Hazinesi Üzerine Bir Araştırma. Yayımlanmamış Yüksek Lisans Tezi. Gazi Üniversitesi Eğitim Bilimleri Enstitüsü.

Yıldırım, A.ve Şimşek, H. (2005). Sosyal Bilimlerde Nitel Araştırma Yöntemleri, (5. Baskı). Ankara: Seçkin Yayıncılık.

Yiğittürk, H. (2005). Orta Öğretim 9. Sinıf Öğrencilerinin Kelime Hazinesi Üzerine Bir Araştırma. Yayımlanmamış Yüksek Lisans Tezi. Gazi Üniversitesi Eğitim Bilimleri Enstitüsü.

Walker, B.; Shippen, M. E; Alberto, P.; Houchins, D. E. and Cihak, D. F. (2005). Using the Expressive Writing Program to Improve the Writing Skills of High School Student with Learning Disabilities. Learning Disabilities Research \& Practice, 20(3), 175-18. 